\title{
The rite of reintegrative shaming in Chinese public dispute mediation
}

\author{
Yongping Ran, Linsen Zhao ${ }^{1}$ and Dániel Z. Kádár ${ }^{2,3}$ \\ ${ }^{1}$ Guangdong University of Foreign Studies $\mid{ }^{2}$ Dalian University of \\ Foreign Languages $\mid{ }^{3}$ Research Institute for Linguistics, Hungarian \\ Academy of Sciences
}

This paper examines the ways in which mediators deploy the rite of public shaming in the activity type of public mediation, as a pragmatic device by means of which they exert social control. Our data consists of episodes of public mediation events in rural China, aired in the Chinese Television. Our analytic framework is anchored to the model of interactional relational rituals: we interpret shaming as a morally loaded communal interactional practice, which the mediator can deploy due to their ratified role, but only within frame of the ritual activity type, and with the communal goal of resolving the conflict. Thus, while ritual forms of shaming may be interactionally intensive - e.g. the person who inflicts shame may inflict shame with little mitigation to put pressure on the shamed person - strict rights and obligations regulate the behaviour of the mediator who needs to act as a 'moral educator'.

Keywords: shaming, mediation, Chinese, reintegration, morality, ritual frame

\section{Introduction}

\subsection{This study}

This paper examines public mediation events in rural Chinese communities. When a major dispute occurs between members of a Chinese family, a professional mediator is often invited to help participants resolve the conflict, particularly if the conflict has financial implications. The mediator orchestrates public mediation, which is an activity type (Levinson 1981) in the course of which participants in the conflict are prompted to resolve the situation. This activity type is ritual: it is centred on rights and obligations (Kádár 2013), it takes place in 
public as a major social drama (Turner 1979) in the rural community and, as such, it is emotively invested. In terms of language use, mediation operates in conjunction with various conventional pragmatic practices, the most important being what we define in this paper as 'the rite of reintegrative shaming'. Reintegrative shaming involves interactional behaviour by means of which the mediator inflicts shame on the participants in the conflict - most often the person who is regarded as being morally responsible for the dispute. This rite of shaming differs from other pragmatic forms of shaming, such as humiliating a person on Facebook (cf. Márquez-Reiter and Orthaber 2018), because it is reintegrative in nature (Braithwaite 1999, 2002), that is, the essence of this ritual is to reintegrate the shamed person into the social group, rather than ostracise her or him. As we will illustrate below, public mediation creates a ritual frame (see Kádár and House 2019a) and a related moral order of things which define the pragmatic boundaries of shaming, within which this reintegration can be achieved. More specifically, since reintegrative shaming takes place in a morally loaded communal event, the mediator must ensure that the style of shaming is acceptable for those members of the public who are observing the mediation event. Interestingly, no previous research has examined reintegrative shaming from a pragmatic angle, and so this paper aims to fill this knowledge gap. As a corpus, we will examine televised dispute mediation (see Section 3).

\subsection{Reintegrative shaming in Chinese mediation events}

Shame is the "master emotion of everyday life" (Scheff 2003, 239), and so inflicting shame is a fundamental resource for exerting social control. Shaming occurs in a number of communal, institutional and public activity types across various settings, as witnessed in families, schools, online communities and so on. While shaming can be highly destructive, it also has the potential to generate a sense of solidarity or rapport (e.g. Scheff 1988; Harris 2009), ${ }^{1}$ and it can be deployed as a communal practice to handle interpersonal conflicts. Such reintegrative manifestations of shaming are generally institutionally or communally endorsed, and this endorsement implies that the person who is inflicting shame is not really expecting to hurt the shamed person - although hurting her or him may be part of the ritual process - but rather to make the shamed person feel morally accountable for the conflict that has triggered the shaming. In Chinese lingua-culture, sham-

1. Note that triggering solidarity is only a potential relational effect of shaming. In other words, while the person who inflicts shame tends to justify it - and usually shaming is a reaction that assumes a moral, normative or ideological breach - as a practice, shaming can be socially or communally divisive (e.g. Braithwaite 1999). 
ing is perceived to be a threat to the shamed person's (moral) face (lian 脸) (see Ran and Zhao 2019). It is important to note here that in Chinese, there are two notions associated with the English notion of face. One - mianzi - is what seems to be the public image, a frontage or façade; the other - lian - refers to the internal: values, morality, and even character. Members of Chinese social groups, particularly those in tight-knit rural communities, tend to be very sensitive to the integrity of their lian, which is the "minimum, irreducible and inviolate face that one must maintain for adequate functioning as a social being" (Ho 1994,279; see also, Hu 1944). The raison dêtre of reintegrative shaming is that communal exposure implies such a strong face threat that it becomes possible to coerce the shamed person into accepting the mediator's solution for the situation, or to successfully prompt the debating parties into working towards a satisfactory resolution of the conflict.

The pragmatic operation of this rite is anchored in rights and obligations (see Kádár and Ning 2019). As in many other communal rites of aggression, public shaming is not institutionalised (see Kádár 2013). Thus, it is an uncodified ritual interactional 'frame' and the moral order of this frame - rather than codified rules and related social order - regulates how such forms of reintegrative shaming are deployed. As Victor Turner $(1979,468)$ argues, communities create 'frames' in which rituals take place and in which rights and obligations differ from those in 'ordinary' life:

To look at itself, a society must cut out a piece of itself for inspection. To do this it must set up a frame within which images and symbols of what has been sectioned off can be scrutinized, assessed, and, if need be, remodelled and rearranged.

In Turner's study, the frame in which a rite of aggression takes place is usually a demarcated area in a communal site where rituals are performed. ${ }^{2}$ Behaviour within this area is regulated by a moral order: the participants of a ritual generally know what is expected and what should be avoided in an aggressive ritual interaction, i.e. how the ritual interaction should unfold. There are few such demarcated areas in the rites of aggression in modern life, and often ritual frames are invisibly present in interactional practices - such as public shaming - in which rights and obligations not only prevail, but also differ from other areas of social life (see Kádár and House 2019a and forthcoming). The concept of a ritual frame is particularly relevant for examining ritual activity types such as public shaming, in which a person is ratified to deploy shaming practices to "scrutinize [and] assess" an inter-

2. Note that Turner (1979) defines such rites as rites of 'antistructure'. Since this technical term has not been used in pragmatics (but see Kádár 2017), we intentionally avoid using it in this paper. 
personal conflict and "remodel" (Turner 1979, 468) interpersonal relationships through reconciliation, and which are bound by a strict moral order on the level of language use.

In the process of mediation, ritual reintegrative shaming unavoidably occurs, as our corpus has revealed (see Section 3). Thus, the rite of shaming is not 'strategic' in these ritual scenarios in Brown and Levinson's (1987) sense because it is expected to occur in the ritual drama of public mediation. In Chinese mediation, the mediator often performs the role of a 'moral educator' (cf. Ran and Zhao 2018), instructing the disputants on how to resolve the interpersonal conflict harmoniously. Consequently, shaming is expected to recur in such contexts, i.e. it is an integral part of the ritual rather than an ad hoc strategy. A mediator generally becomes involved if the conflict is the result of a major moral norm being violated; in our data, this norm is filial piety (xiao 孝), and the mediator becomes involved when young people ignore their duty to support their parents. As a result of this, the mediator is expected to lean towards the party who has been negatively affected by the breach, while at the same time (s)he needs to formally represent both sides. Our research indicates that the way in which mediators resolve the tension between these expectations can vary but, ultimately, they tend to support those who have been affected by the moral trespass, i.e. the father, mother or another older relative (see Section 4.2).

From a pragmatic point of view, the rite of reintegrative shaming is an example par excellence of interactional ritual behaviour, as it shares various distinctive pragmatic characteristics of ritual (see an overview in Kádár 2013, 2017):

1. By default, ritual is a communally oriented form of behaviour, i.e. it helps social structures to reproduce themselves (Goffman 1967; see also Kádár and House 2019a, b). Public mediation as an activity type - and reintegrative shaming as a ritual practice in this activity type - has a very clear communal character.

2. Rituals are anchored in "the normative beliefs/values of a relational network or a broader social group” (Kádár and De La Cruz 2016,265). Reintegrative shaming in ritual mediation is anchored in (primarily Confucian) ideologies: as our analysis will illustrate, the lack of filial piety is a recurrent trope in reintegrative shaming.

3. On an interactional level, the rights and obligations that govern the activity type in which a ritual occurs manifest themselves in a frame for the rite of aggression (see Turner 1979; see also Section 1.1). This frame sets the pragmatic boundaries of language use in the aggressive ritual. Since rites of aggression are usually conventionalised rather than institutional (as in the case of reintegrative shaming), this frame triggers a moral rather than a social or legal 
order (Wuthnow 1989) that the interaction is expected to follow. Due to this moral order, mediators are generally aware of how far they can go with shaming, and what forms of shaming are acceptable in the ritual interaction.

4. Rituals tend to be emotionally invested (Collins 2004) and salient for the participants, as they often transgress the participants' status (this is called 'liminality' in sociology; see, e.g., Turner 1979, 465). Public mediation events are dramas, in which the rite of reintegrative shaming is a fundamental tool used to trigger emotions.

\subsection{Relevance to the pragmatics of ritual}

There are two main forms of ritual shaming, namely, punitive shaming (Boudana 2014; Kádár and Ning 2019), such as marching criminals in front of the public, and reintegrative shaming (Braithwaite 1999, 2002; Barnard 1999) that we are studying here. The former has received significantly more academic attention than the latter, and therefore this paper aims to fill a major knowledge gap.

Our research has implications for pragmatics and linguistic (im)politeness theory because of the aforementioned fact that an invisible moral order of things influences the way in which the mediator deploys the rite of shaming. Recently, a body of pragmatic research has been devoted to the relationship between linguistic (im)politeness and the 'moral order'. Various studies have used Garfinkel's $(1964 ; 1967)$ ethnomethodological approach to the moral order to explore how perceptions of (im)politeness interrelate with "the 'take for granted' or 'seen but unnoticed', expected, background features of everyday scenes" (Haugh 2013,57; see, e.g., Davies 2018; Tayebi 2016). Another group of studies has examined the moral order in scenes where moral ideologies, norms and values influence the ways in which an interaction is expected to unfold (e.g. Kádár 2017; Kádár and Fukushima 2018; Márquez-Reiter and Orthaber 2018; Parvaresh and Tayebi 2018; Spencer-Oatey and Kádár 2016; Tayebi 2016; Zhao and Ran 2019). Within this latter area of research, various scholars have explored the ways in which interpersonal conflict interrelates with negotiations/perceptions of (im)morality and (im)politeness (e.g. Horgan 2019; Georgakopoulou and Vasilaki 2018; Graham 2018; Kienpointner 2018; Kádár and Márquez-Reiter 2015; Kádár et al. 2019; Sinkeviciute 2018), and this paper contributes to this research. The ritual frame (Turner 1979) that the activity type of public mediation triggers is noteworthy in the respect that such scenes - and the rite of aggression in them - take place outside the realm of routine everyday interaction (Garfinkel 1964;1967), and, as such, the moral order of things that participants and observers expect to happen is, in a sense, extraordinary (i.e. it is not what is 'seen but unnoticed'). Conflictive ritual interactional practices, like reintegrative shaming, are not only dramatic but 
potentially upsetting to many, and yet they are expected to take place when the ritual public mediation is deployed.

As the examples in this paper will illustrate (Section 4), in terms of (im)politeness, the mediator has relative freedom with regards to how (in)directly (s)he inflicts shame on the person who is perceived to be responsible for the conflict. In other words, the mediator might attempt to overwhelm the shamed person by intensifying the act of shaming, or alternatively might attempt to mitigate the shame. One can observe significant variation in the degree of (in)directness in reintegrative shaming practices, although the public nature of shaming is inherently face threating. A phenomenon worth noting for (im)politeness theory is that, in reintegrative shaming, language use cannot become overtly abusive. In such scenarios, even direct forms of shaming are relatively disarmed in that they lack the pragmatic inventory, such as sexually loaded references, that normally characterise shaming. What interconnects all the manifestations of reintegrative shaming is intensive moralisation: our data analysis reveals that the mediator makes continual metapragmatic appeals to moral norms and ideologies that the behaviour of the shamed person is perceived to have violated (Kádár and Márquez-Reiter 2015), in order to demonstrate that shaming is ratified.

Our paper has the following structure. In Section 2 we will provide a brief overview of previous research on shaming in order to position our research in the field, and we will introduce our corpus in Section 3. We will analyse examples that have been drawn from this corpus in Section 4, and this section will be divided into two parts. First, we will examine those cases in which the mediator intensifies shaming instead of mitigating it, an interactional form of behaviour that we define as 'amplification'. We will highlight that even 'amplified' forms of shaming remain morally loaded and, to a certain degree, disarmed in mediation sessions. Second, we will examine the mitigated use of shaming in mediation sessions. These cases illustrate the aforementioned point that the mediator has relative freedom with regards to how (in)directly they deliver shaming, provided that the rite of reintegrative shaming is maintained within the ritual frame of public mediation. Finally, Section 5 will summarise the findings of the paper.

\section{Previous research on shaming}

In sociology, shame has been interpreted as being a driving force for constraints which determine individual behaviours within social and moral boundaries (e.g. Etzioni 2001; Scheff 2003; Taylor 1985; Williams 1993). Accordingly, previous sociological research on shaming has approached this phenomenon as a means of exerting social control, i.e. a social practice "through which one person attempts 
to instil a sense of shame in another" (Lo and Fung 2011,173), wherein shame (as opposed to 'guilt') is a "self-conscious emotion" that can arise when people negatively evaluate themselves due to a legal and/or moral breach they have committed (Welten et al. 2012,836). Shame is "fundamentally central to influencing and regulating the way we think, feel, and act" (Lewandowska-Tomaszczyk and Wilson 2017,1). When someone is shamed, this person normally feels they are being exposed to the disapproval of others. Therefore, it is claimed that shaming has the power to coerce people into adhering to moral orders in situations where their behaviour may not violate the social order, i.e. to accept the hierarchies, constraints and affordances of social groupings, and construct their interactional behaviour accordingly (Boyer 1978,34).

Previous pragmatic research has primarily focused on shame as a feeling, rather than shaming as a social (self-)regulatory practice. For instance, Culpeper $(2011,62)$ has highlighted that violations of face can trigger the self-conscious emotions of embarrassment and shame. Spencer-Oatey $(2002,534 ; 2005,116)$ has demonstrated that people can feel ashamed if they perceive that their rapport with others has been damaged or neglected. Kádár and Márquez-Reiter (2015) and Kádár (2017) have argued that failure to perform practices that individuals or communities expect - e.g. the failure to ritually support a person who is being abused in public - often triggers a sense of shame. Recently, various scholars (e.g. Márquez-Reiter and Haugh 2019; Zhao and Ran 2019) have examined the connection between impoliteness and moral self/face. Márquez-Reiter and Haugh (2019) contend that public denunciations, such as blaming, frequently occur in public spheres, which involve the ritual destruction of the target's moral self or moral standing. While shaming has been noted in recent pragmatic research, the ritual of reintegrative public shaming has not been mentioned.

We attempt to bring the aforementioned sociological understanding of shaming as a social regulatory process into pragmatics: we intentionally limit our analysis to cases in which public shaming plays an important role in the resolution of an interpersonal conflict (see Section 1.1). It is important to note that we are not trying to argue that shaming - even in a regulated, institutionalised and ritual reintegrative form - is a positive phenomenon for everyone, as it is clear that it is undesirable and coercive for the shamed person. As we have already noted, finding a resolution does not necessarily translate into being nice: even though, in our corpus, reconciliation follows the process of shaming, this reconciliation is often the result of coercion. This is why the sociological understanding of shaming as a form of 'control' is essential for this study. Notably, this sense of social control is particularly strong if ritual shaming takes place in the mass media such as television, newspapers and social media (cf. Curran 2005; Every 2013; Heo and Park 2017; Petley 2013; Rowbottom 2013). It is no coincidence that 
our corpus comprises televised mediation events. The key power behind shaming in the media is "exposure" (Madianou 2011,3): if a person is publicly shamed in the media, his/her alleged moral trespass will be publicly disclosed and contrasted with the social order.

It is worth noting that interconnecting the process of inflicting shame with the (self-)regulation of social groups is not our sole contribution to linguistic pragmatics. Various sociolinguists with an interest in pragmatics have explored this area (e.g. Ho 1986; Schieffelin 1986; Fung 1999). For instance, Schieffelin (1986) argues that adults employ both teasing and shaming routines (including name-calling, rhetorical questions, sarcastic statements, third-party threats, etc.) to teach children how to become respected members of Kaluli society. In a rather similar way, Fung (1999) investigates how shaming takes place in Chinese families by using a longitudinal, ethnographic approach: the results of this research show that parents employ both explicit (e.g. labelling such as 'shame on you', 'ashamed' and 'losing face') and implicit (e.g. mockery or sarcasm) means to shame children in an attempt to teach them right from wrong, and to alter their behaviour.

\section{Data}

Televised mediation is very popular in China because of the moralising character of the mediation episodes and the cultural tradition of resolving conflict through community mediation (see, e.g., An and Peng 2013; Deng et al. 2013; Hawes and Kong 2013; Li 2009; Ran and Zhao 2018). According to Hawes and Kong $(2013,763)$, Chinese mediators prefer public shaming to settle differences between disputants and to "exert social and peer pressure on disputants to 'do the right thing"'. As China has undergone many social changes during the rapid industrialisation and urbanisation of recent years, concerns about parental care, marital conflicts and other controversial family issues have been growing, particularly in rural village communities. This is evidenced by the many televised dispute mediation programmes which deal with marital crises and family disputes, particularly those between parents and their adult children (usually involving parental maintenance disputes). Thus, there is an abundance of data for researching ritualmediated and related shaming practices. In our project, we have collected data from the TV programme Feichang Bangzhu 非常帮助 (Special Help), which was produced by the Nongmin 农民 (peasantry) Channel of Hebei Province Television. ${ }^{3}$ This programme is a documentary series: it takes place in real-life rural settings where an expert mediator is invited by a village representative (cunzhang 村长), or another person, to mediate in a conflict. Participants are aware that

3. A weblink to the programme can be found at: http://fcbz.nongmintv.com/ 
the event is being televised, i.e. this is a planned documentary rather than a flyon-the-wall programme. From an analytical perspective, it is particularly interesting to note that each episode takes place in a conventional rural community with the involvement of mediation experts who, outside of the show, also work as expert folk mediators. As a corpus we collected 30 televised episodes of mediation, which all involved parental maintenance disputes, over a period of six months. The actual mediation session in each episode ranged from 10 to 30 minutes in duration.

It should be noted that in the following transcripts the pseudonym ' $M$ ' refers to the mediator, 'W' refers to the alleged wrongdoer - usually the person who is refusing to support his/her parents - 'V' refers to the alleged 'victim' of this lack of support, i.e., the father or mother of the shamed person, while 'B' refers to the bystanders who observe the mediation sessions (fellow villagers).

'Filial piety' (xiao 孝) is a fundamental moral norm in traditional Chinese culture, and it is associated with a set of values such as respect, care, responsibility, affection and repayment (e.g. Sung 1998; Yang 2012). There are many different ways in which this norm can influence Chinese pragmatic behaviour, and our research only features a single albeit important case, namely, when it is perceived to be breached. When such a transgression of xiao occurs, many in Chinese society expect a punitive and reintegrative reaction to unfold, particularly in settings such as Chinese villages where, even now, the community tends to have a sense of conventional power over the individual. The moral discourses in conflict mediation - particularly when reintegrative shaming is deployed - revolve around the unwillingness of adult children/a younger relative to support their parents/older relatives. In such incidents, the mediator endeavours to arouse the trespasser's sense of shame, hence coercing him or her to show filial piety by providing a living allowance or a promise to provide more care for the neglected parent/senior relative. Both the double-articulated nature of the mediation event and the presence of other villagers, such as neighbours, at these sessions place significant pressure on the shamed person to accept the solution proposed by the mediator. It is worth noting that, in the majority of our cases, the conflict revolves around money because, in Chinese lingua-culture, children are duty-bound to financially support their parents.

The sequence of the mediation events in our corpus is as follows:

1. The mediator discusses the trespasser's transgression of xiao (i.e. adult children refusing to support their parents).

2. The mediator ritually shames the trespasser by following a moral order (i.e. by maintaining shaming within certain boundaries). Shaming may trigger interactional struggles. 
3. Ultimately, the trespasser is coerced: (s)he agrees to offer money to the neglected relative. Coercion involves accepting the public shaming and committing oneself to reforming one's behaviour.

All 30 cases in our corpus operate with this sequential structure.

\section{Analysis}

If one examines the interactional style of the mediator in our corpus, it becomes evident that:

- The mediator needs to engage in extensive moralisation in the form of metapragmatic appeals to moral norms and ideologies to maintain the communal and constructive character of shaming.

- In terms of (in)directness, the mediator can choose different interactional styles of shaming to increase the efficiency of the mediation. However, (s)he needs to ensure that shaming is kept under control, for otherwise this would contradict the communally endorsed nature of this ritual and the role of the mediator as a person who has been ratified to act as a moral educator.

To illustrate this latter point, we divide our analysis into two sections: we analyse cases in which either (1) the intensity of exerting pressure on the shamed person is amplified, i.e. there is a sense of impoliteness involved in the mediation, or (2) shaming is mitigated.

\subsection{Amplifying shame}

Chinese ritual shaming practices can be "amplified", i.e. they can be made "direct, unmitigated and affectively intensified" (Lo and Fung 2011, 174). Mediators can amplify shame by using two interrelated pragmatic tools: (a) They can inflict shame on the person who is perceived to have caused the conflict in an explicit and repetitive manner, and (b) they can recruit bystanders for the shaming event. In instances of 'amplification', shaming operates in a relatively unmitigated way. In reintegrative ritual shaming, such attacks have a complex relationship with impoliteness due to the communal ritual nature of the activity type of mediation. Firstly, as we have noted above, the mediator cannot trespass certain pragmatic boundaries, but rather is expected to speak in the manner of a moral educator. This differs from some other (non-integrative) forms of shaming, in which the person who is inflicting shame uses expletives, mocks the physical characteristics or sexuality of the shamed person, and so forth. Secondly, the majority of the 
community endorses this behaviour, hence the involvement of the mediator, and therefore the mediator can always appeal to the public. Thus, while the rite of reintegrative shaming can cause serious offence (cf. Culpeper 2011) to the shamed person, such offence is only a side effect, rather than the goal of this behaviour.

The following Examples (1) and (2) illustrate this phenomenon:

(1) In this conflict, $M$ is V's daughter-in-law. She refuses to support V because V wants to take back the house he gave $\mathrm{W}$ several years ago. $\mathrm{M}$ has been invited by $\mathrm{W}$ to her home, the house that $\mathrm{V}$ wants to take back.

$01 \mathrm{~W}$ : (对 $M$ )当着帮大哥 $(M)$ 呢，乡亲们都看着呢，(他)就为了那个房 子。

(To M) Since Brother Bang (M) is here and since our fellow villagers are watching, I tell you the truth: he is intent on getting the house back.

$02 \mathrm{M}$ : (对W) 不是，你跟我好好说，他是怎么说这个事。 (To W) Bushi (not-be), calm down and tell me what he said.

$03 \mathrm{~W}$ : (对V) 不嫌臊, 不要脸!一天披着个人皮，不嫌臊！ (To V) Buyaolian! (Shame on you! lit., You don't want moral face!) You are a shameless creature in human's clothes. Shame on you!

$04 \rightarrow \mathrm{M}$ : 那你这样老骂，这是谁啊？你怎么老骂他啊？

You are repeatedly scolding him. Who is he? Why do you keep scolding him?

$05 \mathrm{~W}$ : 你跟我说话。

You are speaking for me now.

$06 \rightarrow \mathrm{M}$ : 不是，你怎么老骂他啊，这是谁啊？

No, why do you keep scolding him? Who is he?

$\mathrm{W}$ : 你别管他是谁。你是来我家给我办事的。

It doesn't matter who he is. You are invited here to solve the problem on my behalf.

o8 M: 这不是你老公公啊?

He is your old father-in-law, isn't he?

$09 \mathrm{~W}$ : 你说是让说话, 还是不让说话?

Are you gonna let me talk or not?

$\mathrm{M}$ : 不是，这不是你老公公啊?

No, isn't he your old father-in-law?

$\mathrm{W}$ : 这样说吧, 你是叫我跟你说话, 还是让别人跟你说话?

Well, do you want to talk to me or to someone else?

$\mathrm{M}$ : 我让你说话啊。

I let you talk.

$\mathrm{W}$ : 你叫我说，那你让别人说什么话啊?

You let me talk? Why do you let him talk? 
$14 \rightarrow \mathrm{M}$ : 但是你不能骂人家啊!

But you can't scold him!

15

$\mathrm{W}$ : 我不能骂他?

I can't scold him?

$16 \rightarrow \mathrm{M}$ : 这不是你老人啊? 这是孩子的爷爷，你能老骂他啊？你老骂 他，这个事就不对了! 大家伙不笑话你啊!

Isn't he your elder? He is your children's grandfather. How can you scold him repeatedly? It is wrong for you to scold him. Everyone would laugh at you!

I don't care if they laugh at me!

$18 \rightarrow \mathrm{M}$ : 哪有媳妇说老公公, 张嘴“不要脸不要脸”的骂! (W沉默)

Who has ever seen a daughter-in-law who insults her father-in-law by saying "shame on you" again and again! (W keeps silent).

In line $1, \mathrm{~W}$ voices her complaint against her father-in-law $\mathrm{V}$ by arguing that he wants to take back the house he gave $\mathrm{W}$ several years ago. In lines 2 and 3, a disagreement occurs between $\mathrm{W}$ and the mediator $\mathrm{M}$ : when $\mathrm{M}$ requests $\mathrm{W}$ to provide more information, $\mathrm{W}$ scolds $\mathrm{V}$, exclaiming that he 'does not want moral face' (buyaolian 不要脸). From line 4 onwards, $M$ engages in the practice of ritually shaming W, by recurrently focusing on the inappropriate way in which $\mathrm{W}$ scolded V. His interactional style reflects the manner in which the moral order influences how mediators are expected to speak: he cloaks his attacks on W's moral face in the quasi-parental style of a moral educator.

In line $5, \mathrm{~W}$ attempts to divert shaming by claiming that she does not care who $\mathrm{V}$ is. However, $\mathrm{M}$ sanctions this as a further offence, by repeatedly emphasising V's identity as the old father-in-law (lines 8 and 10). $\mathrm{M}$ implies that V should be ashamed that she has abused an older relative (note that in the traditional Chinese view, $\mathrm{V}$ is a quasi-father to his daughter-in-law, W). In so doing, V's lian is threatened since her moral transgression is being highlighted by M. It is worth noting that W challenges M's intervention by appealing for permission to speak (lines 9 and 13), i.e. she perceives M's behaviour to be a form of what we describe in this paper as 'amplification' (see Section 1.3).

In line $7, \mathrm{~W}$ challenges $\mathrm{M}$ by stating that the mediator is expected to represent her interests as well. $\mathrm{V}$ thinks $\mathrm{M}$ should listen to her because she had invited $\mathrm{M}$ to the house. This move is notable because it highlights the complex role of the mediator (see Section 1.2) who, in theory, must represent both sides in a conflict. However, $\mathrm{M}$ does not support $\mathrm{W}$, but continues to inflict shame on her for her disrespectful treatment of V. In line 16, M threatens $\mathrm{W}$ by saying that her repeated insulting of $\mathrm{V}$ could become a source of ridicule among the community. At this point, V's lian is under serious threat, as the community of a Chi- 
nese village places great importance on the individual (see Ho et al. 2004). While M's utterance is certainly both face threatening and emotionally overwhelming, in that it consists of a chain of direct persuasive attacks, it is communally oriented and, as such, it does not violate the role of $\mathrm{M}$ as a moral educator. As the interaction unfolds, $\mathrm{W}$ becomes defensive and, in line 18, $\mathrm{M}$ manages to coerce her into silence.

The following example represents another case in which shaming is delivered in an increasingly intensive fashion:

(2) (W is V's son. W refuses to provide a living allowance for his mother V.

$01 \mathrm{~W}$ : 我掏不出来, 我不是说我不掏。

It's not because I don't want to provide her the allowance. It's

because I don't have the money.

$02 \mathrm{M}$ : 掏不出来，一点都掏不出来吗?

You don't have the money? Even a little?

[...]

03 $\rightarrow \mathrm{M}$ : 咱这样，你问问乡亲们，让大家都看看，你这个养老应该不应 该?

Let's do this, you ask the fellow villagers to consider whether or not you should support your mother.

04 B: 肯定是应该。

Of courseyou should.

$05 \rightarrow \mathrm{M}$ : 啊，对不对？你这个养老应该不应该？你有多少理可讲？(看 着旁观者，指着W)

Yeah, right? Shouldn't you support your parents? How many excuses do you have? (Looks at the bystanders and points to W.)

$06 \mathrm{~W}$ : (对V) 你就看不起我, 你就一步一步, 你想把事逼到这，你把 家里东西给了别人，我给你出东西，我该出？!

(To V) You just look down upon me. You have trapped me into where we are. You have given the family wealth to others but are now demanding money from me. Why should I?

$07 \rightarrow \mathrm{M}$ : 别说了, 够丢人的了, 兄弟! 别说了! 你看看大家都说你什 么? ! (W沉默)

Stop talking! Brother, that's too shameful! Stop talking! You just look around, and see what others talk about you?! (W keeps silent.)

Initially, $\mathrm{M}$ makes an attempt to persuade $\mathrm{W}$ to take responsibility for his mother, but $\mathrm{W}$ refuses to accept this. In turn, $\mathrm{M}$ recruits W's fellow villagers (lines 3, 5 , and 7) because enlisting the support of others can increase the weight of the reproach and amplify the sense of shame. It is worth noting that engaging in the recruitment of others is a typical form of interactional behaviour in communal 
ritual activity types (cf. Kádár and De La Cruz 2016; Kangasharju 2002). After receiving a bystander's response, $\mathrm{W}$ continues the amplified shaming of $\mathrm{W}$ by making continuous appeals to xiao and the devastating implication of ignoring one's own mother. In keeping with the mediator in Example (1), here M continuously threatens W's face but maintains the attacks within the ritual frame as he continues to speak as a ratified moral educator. In line $6, \mathrm{~W}$ turns to his mother and attempts to divert shaming by blaming her, in a rather similar fashion to $\mathrm{W}$ in Example (1) (lines 9 and 13) when she blames the mediator. In line 7, M disapproves of this move and orders W to "stop talking". This 'bald on record' utterance is abrupt, and it reflects M's status as an educator who is in control of a situation where one of the participants continuously trespasses a major moral norm. He further increases the face-threat produced by his abrupt utterances when he reminds $\mathrm{W}$ that his attitude towards his mother will be negatively judged by other villagers and he could lose lian, thus becoming ostracised and unwanted. This threat silences W.

In this section, we have examined cases in which the mediator amplifies reintegrative shaming, by delivering explicit and repetitive evaluations of the inappropriate behaviour of the person who trespassed the norm of xiao. These evaluations threaten the shamed person's moral face in the village and, as such, represent a highly efficient way to achieve coercion. Taking into consideration that the ritual activity type of mediation is a public affair, failure to conform with the mediator's suggestion can have grave repercussions. The mediator is ratified to recruit other villagers, hence intensifying the pressure on the shamed person. At the same time, the mediator's attacks are always maintained within the pragmatic boundaries of the ritual. The mediator speaks as a moral educator, and even if his/her words cause offence, this offence is only created to ultimately resolve the conflict.

\subsection{Mitigating shame}

In addition to the amplification of shaming, the mediator can also mitigate ritual reintegrative shaming, as the following Examples (3) and (4) illustrate:

(3) W is V's son. W did not support $\mathrm{V}$ for some time and, as a result, has been disowned by $\mathrm{V}$.

$01 \mathrm{~V}$ : (对 $\mathrm{M}$ ) 你问他交过几回钱，我多大都养活你，你养我多少呀? 你生下来就能长大? 谁生下来就能长大呀?

(To M) You ask him how often he has given me money. (To W) I supported you all along. How much have you supported me? Can anyone grow up by himself?

(To V) Why did you disown me?

[...] 
03 $\rightarrow \mathrm{M}:$ (对V) 孩子现在成这个样(不守孝道)，与你有一定的责任，当 老人的有责任，不管到嘛年月你得承认。现在咱不管怎么讲， 虽然咱老了，但还没老到一定的程度，还有责任把他教育帮助 帮助。

(To V) Now the child has become like this (i.e. not conforming to the norm of xiao; authors' addition). You should have taken some responsibility for that. Parents are always responsible for their children. You are a bit old now, but still young enough to be dutybound to help and educate him (on the norm of xiao; our addition). $04 \rightarrow \mathrm{M}$ : (对W) 你听我给你说说，这不刚才说了，这么多年了，你也不 是三岁两岁的小孩了, 你也应该懂事了, 这不刚才说你爸爸 了，是吧？虽然“子不教父之过”，但是你自身这么大岁数了， 应该懂呀，是吧？好多社会上的这些道德呀礼仪呀，你应该知 道，是吧？孝敬父母，也是每个子女应尽的义务，但是你现在 没有做到孝敬父母。(W点头)

(To W) Listen to me. As I just mentioned, you are not a three-yearor two-year-old anymore. You should know better. Just now, I put the blame on your father, right? As the saying goes "Father is to blame for his son's faults", you know that, right? You understand social ethics and etiquette, right? Children have a duty to support their parents (lit. Children should conform to the norm of 'filial piety'), but you fail to do so. (W is nodding his head.)

In this case, $M$ employs a balancing strategy to "make both parties appear to be evenly matched" (Deng 2012,442), by inflicting a certain sense of shame on both parties. On the one hand, $\mathrm{M}$ implicitly accuses $\mathrm{V}$ of not being a good father because he has neglected his duty to properly educate his son on the importance of conforming to the norm of xiao (line 3 ). On the other hand, he shames $\mathrm{W}$ for trespassing filial piety (line 4). It is important to emphasise that $\mathrm{W}$ is confronted with the greater extent of the shaming and related threat of moral face. In other words, $\mathrm{W}$ is the primary person to be shamed and, ultimately, he needs to adhere to the norm of xiao by agreeing to offer money to V. In this sense, the mediator mitigates the reintegrative shaming vis-à-vis the balancing strategy.

Besides, when $\mathrm{M}$ inflicts shame on $\mathrm{W}$, he recurrently uses the tag question shiba 是吧 (right?) in order to make $\mathrm{W}$ accept the moral order of xiao. In this case, tag questions serve to attenuate the force of opinions and, as such, they fulfil a negative politeness function (Brown and Levinson 1987).

The following Example (4) further illustrates the operation of mitigated shaming in our corpus: 
(4) W is V's son. W disagrees that he should offer a monthly allowance to V.

$01 \mathrm{~V}$ : 他每天挣了钱了。这不是小工们啊?

He earns money every day. They are (your) employees, aren't they?

02

$\mathrm{W}$ : 我能挣多少钱啊？我都没活干!

How much money can I earn? I have no contracts.

$03 \rightarrow \mathrm{M}$ : 你还是老板呢! 还是老板呢! (笑并看着旁观者)

You are a boss! You are a boss! (Smiling and looking at the

bystanders.)

04

$\mathrm{W}$ : 我是老板。(乡亲们笑着点头)

I am a boss. (The villagers are nodding and smiling.)

$05 \rightarrow \mathrm{M}$ : 你看这么多乡亲们点头。这老板还领导着工人，给老娘拿三百 块钱，一个月零花钱都拿不出来！那你给工人发工资不?

You see, so many of your fellow villagers are nodding their heads. As a boss, you hire so many workers. If you cannot give your mother 300 yuan, not even for one month, as pocket money, how can you pay your workers?

06

$\mathrm{W}$ : 我早不发了, 从今天结束了。

I haven't paid them for a long time - My business is closed down as of today.

$07 \rightarrow \mathrm{M}$ : 你看看你现在这情况啊，一有厂房，二有工人，小小老板当 着, 再一个又有车, 老人的地你也种着。咱这么说, 你现在就 是说, 老人给你要这个也没有, 要那个也没有。咱自己要对住 咱的良心了，你就这样做下去。就这么简单，咱也不说。这反 正，说一千道一万，这是你的亲茤亲娘。(W沉默)

Look at your situation: you are a small business owner who has a car, a factory and employees. Also you are planting your parents' land. Let us put it this way: you have nothing to offer when your parents ask you for something. If you really don't feel guilty, go ahead and continue to do this. It's very simple. We do not need to talk anymore. After all, they are your parents. (W keeps silent.)

In this dispute, $\mathrm{M}$ repeatedly accuses $\mathrm{W}$ of being miserly, despite being a boss (lines 3, 5 and 7). This positive assessment of $\mathrm{W}$ as a boss managing factory employees reflects an attempt on the mediator's part to be polite. Moreover, M's ritual teasing is open to interpretation as an indirect 'offer' to form alignment between the mediator and the shamed person (cf. Kádár 2017). M invites W and the bystanders to relate to W's transgression in an amusing tone of voice. The entire episode is filled with smiles, laughter and body gestures and, ultimately, W is coerced into agreeing to pay a monthly sum to his parents. This example illustrates that the ritual of public shaming can be manipulated in a playful and polite frame, thus providing a simple way for the wrongdoer to compromise. While the 
style of the mediator in this extract could be interpreted as being 'mock polite' (cf. Culpeper 1996), the mediators in our corpus do not mock the shamed person in the strict sense of the word. This lack of mocking is logical when one considers that the mediator, as a moral educator, needs to demonstrate that (s)he is serious. Thus, the interactional style of the mediator in Example (4) is ultimately more amiable than mocking.

In this section we have examined cases in which shaming occurs in a mitigated form in our data. While such forms of mitigation can indicate the intention to be polite, they concur with coercion in a similar way to the amplifying behaviour studied in the previous section. Thus, in such cases, the mediator also engages in moralising appeals and speaks as a moral educator. This illustrates that a key ritual constraint for the mediator is ensuring that shaming is morally loaded.

\section{Conclusion}

This paper has explored the ways in which mediators utilise the rite of reintegrative shaming as a form of social control in ritual activity type of mediation in Chinese rural communities. As this study shows, the shaming undertaken by a mediator is a ritual practice that "re-enacts the ideologies or ethos of a relational network or broader social group as a 'performance', and generates intense emotions and affection (relational emotions)” (Terkourafi and Kádár 2017, 172). In the case of the Chinese corpus studied, this ideology is the importance of the Confucian norm xiao.

Our data analysis has revealed that shaming takes place in a ritual frame (Turner 1979), which enables the mediator to play with (in)directness. While the moral order of this frame prevents the mediator from becoming too personal when shaming, the mediator can inflict shame in a diverse range of ways. Yet, irrespective of the style, the mediator almost always engages in extensive moralisation to maintain shaming within the boundaries of the ritual frame, by speaking as a 'moral educator'. This demonstrates that ritual shaming is not an ad hoc act, but rather it operates with an intrinsic underlying moral order. In an ethnomethodological sense, conflict represents an extraordinary rather than an ordinary scene (Section 1.1). However, it is clear that the concept of moral order is key to understanding the interactional dynamics of shaming as a ritual practice, similar to ordinary, 'seen but unnoticed' scenarios).

Our analysis has demonstrated that shame is closely associated with the loss of honour. Here, honour can be termed 'moral face', referring to the reputation or public acknowledgement of one's worth (see also Ho et al. 2004; LewandowskaTomaszczyk and Wilson 2017; Stewart 2015). A person's 'moral face' is based on 
the recognition of a person's conformity with norms and values. Mediators often manipulate the conversation by making appeals to 'moral face' as they threaten the shamed person with diulian 丢脸 'losing moral face'.

The mediator and public audience tend to jointly accomplish shaming. For mediators, shaming is not in itself the ultimate goal, but a means to coerce trespassers into accepting the moral norms of society, and therefore they utilise various forms of persuasion with differing degrees of (in)directness.

This investigation of reintegrative shaming in Chinese mediation events illustrates the importance of communal rituals in pragmatic research. As a result of the ritual frame, in communal rites the rights and obligations of the participants are conventionalised but not institutionalised and, as such, are subject to interactional struggles. We hope that this paper will generate further academic interest in the pragmatics of Chinese rituals, and in particular Chinese communal rites of aggression.

\section{Funding}

Research funded by Lendulet Grant of the Hungarian Academy of Sciences (LP2017/5) to Daniel Kadar and by Chinese Ministry of Education (16JJD740007).

\section{Acknowledgements}

The research of Yongping Ran and Linsen Zhao has been funded by both Department of Education of Guangdong Province and Center for Linguistics and Applied Linguistics at Guangdong University of Foreign Studies, P.R. China for the project of the frontier research and its theoretical innovations in interpersonal pragmatics (2018WZDXMoo6). Daniel Z. Kadar's research has been funded by the MTA Momentum (Lendulet) Research Grant (LP2017/5). On the personal level we would like to say thank you to Juliane House for her insightful suggestions regarding our research, and also to Rosina Marquez Reiter and Hemut Gruber for all the editorial support they provided us.

\section{References}

An, Meili, and Minge Peng. 2013. “On Mediators' Management of Disagreement with Disputants in Chinese Televised Dispute Mediation." Journal of Asian Pacific Communication 23 (1): 14-165.

Barnard, Jayne W. 1999. Reintegrative Shaming in Corporate Sentencing. Retrieved from: https://scholarship.law.wm.edu/cgi/viewcontent.cgi?referer=https://www.google.com $/$ \&httpsredir $=1$ \&article $=1333 \&$ context $=$ facpubs 
Boudana, Sandrine. 2014. "Shaming Rituals in the Age Of Global Media: How DSK's Perp Walk Generated Estrangement." European Journal of Communication 29 (1): 50-67. https://doi.org/10.1177/0267323113509361

Boyer, Paul S. 1978. Urban Masses and Moral Order in America, 1820-1920. Cambridge, MA: Harvard University Press.

Braithwaite, John. 1999. Crime, Shame and Reintegration. Cambridge: Cambridge University Press.

Braithwaite, John. 2002. "Repentance Rituals and Restorative Justice." The Journal of Political Philosophy 8 (1): 115-131. https://doi.org/10.1111/1467-9760.00095

Brown, Penelope, and Stephen Levinson. 1987. Politeness: Some Universals in Language Usage. Cambridge: Cambridge University Press. https://doi.org/10.1017/CBO9780511813085

Collins, Randall. 2004. Interaction Ritual Chains. Princeton, NJ: Princeton University Press. https://doi.org/10.1515/9781400851744

Culpeper, Jonathan. 1996. “Towards an Anatomy of Impoliteness.” Journal of Pragmatics 25 (3): 349-367. https://doi.org/10.1016/0378-2166(95)00014-3

Culpeper, Jonathan. 2011. Impoliteness: Using Language to Cause Offence. Cambridge: Cambridge University Press. https://doi.org/10.1017/CBO9780511975752

Curran, James. 2005. "Communications, Power and Social Order." In Culture, Society and the Media, ed. by M. Gurevitch, J. Curran, and T. Bennett, 198-231. London: Routledge.

Davies, Bethan L. 2018. "Evaluating Evaluations: What Different Types of Metapragmatic Behaviour Can Tell Us about Participants' Understandings of the Moral Order." Journal of Politeness Research: Language, Behaviour, Culture 14 (1): 121-151. https://doi.org/10.1515/pr-2017-0037

Deng, Yiheng. 2012. "Strategy to Alleviate Adversity in Chinese Mediation: A Discourse Analysis on Real Chinese Mediation Sessions." Chinese Journal of Communication 5 (4): 417-436. https://doi.org/10.1080/17544750.2012.723386

Deng, Yiheng, Kaibin Xu, Xiaoqiu Fu, and Sang Ma. 2013. "Mediating Conflict on TV: A Discourse Analysis of the Gold Medal Mediation Episodes." China Media Research 9 (4): 5-14.

Etzioni, Amitai. 2001. The Monochrome Society. Princeton, NJ: Princeton University Press. Every, Danielle. 2013. “'Shame on You': The Language, Practice and Consequences of Shame and Shaming in Asylum Seeker Advocacy.” Discourse \& Society 24 (6): 667-686. https://doi.org/10.1177/0957926513486223

Fung, Heidi. 1999. "Becoming a Moral Child: The Socialization of Shame among Young Chinese Children.” Ethos 27 (2): 180-209. https://doi.org/10.1525/eth.1999.27.2.180

Garfinkel, Harold. 1964. "Studies of the Routine Grounds of Everyday Activities." Social Problems 11: 225-250. Republished in Studies in Ethnomethodology, 35-75. Englewood Cliffs, NJ: Prentice-Hall, 1967.

Georgakopoulou, Alexandra, and Maria Vasilaki. 2018. "The Personal and/as the Political: Small Stories and Impoliteness in Online Discussions of the Greek Crisis." Internet Pragmatics: Special Issue - (Im)politeness and Moral Order in Online Interactions 1 (2): 215-240. https://doi.org/10.1075/ip.ooo11.geo

Goffman, Erving. 1967. Interaction Ritual: Essays on Face-to-Face Behavior. New York: Anchor Books.

Graham, Sage L. 2018. "Impoliteness and the Moral Order in Online Gaming." Internet Pragmatics: Special Issue - (Im)politeness and Moral Order in Online Interactions 1 (2): 303-328. https://doi.org/10.1075/ip.00014.lam 
Harris, Alexes. 2009. "The Role of Power in Shaming Interactions: How Social Control Is Performed in a Juvenile Court." Contemporary Justice Review 12 (4): 379-399. https://doi.org/10.1080/10282580903342854

Haugh, Michael. 2013. "Im/politeness, Social Practice and the Participation Order." Journal of Pragmatics 58: 52-72. https://doi.org/10.1016/j.pragma.2013.07.003

Hawes, Colin, and Shuyu Kong. 2013. "Primetime Dispute Resolution: Reality TV Mediation Shows in China's 'Harmonious Society'. Law \& Society Review 47 (4): 739-770. https://doi.org/10.1111/lasr.12046

Heo, Mansup, and Jaeyung Park. 2017. "Shame and Vicarious Shame in the News: A Case Study of the Sewol Ferry Disaster." Journalism 2: 1-19.

Ho, David Yau-Fai. 1986. “Chinese Patterns of Socialization: A Critical Review." In The Psychology of the Chinese People, ed. by H. B. Michael, 1-37. Hong Kong: Oxford University Press.

Ho, David Yau-Fai. 1994. "Face Dynamics: From Conceptualization to Measurement." In The Challenge of Facework, ed. by S. Ting-Toomey, 269-286. New York: State University of New York Press.

Ho, David Yau-Fai, Wai Fu, and S.M. Ng. 2004. "Guilt, Shame and Embarrassment:

Revelations of Face and Self." Culture and Psychology 10 (1): 64-84. https://doi.org/10.1177/1354067X04044166

Horgan, Mervyn. 2019. "Everyday Incivility and the Urban Interaction Order: Theorizing Moral Affordances in Ritualized Interaction." Journal of Language Aggression and Conflict: Special Issue - Morality, the Moral Order, and Language Conflict and Aggression 7(1): 31-54. https://doi.org/10.1075/jlac.00018.hor

$\mathrm{Hu}$, Xianjin. 1944. "The Chinese Concept of Face." American Anthropologist 46: 45-64. https://doi.org/10.1525/aa.1944.46.1.02a0oo40

Kádár, Dániel Z. 2013. Relational Rituals and Communication: Ritual Interaction in Groups. Basingstoke: Palgrave Macmillan. https://doi.org/10.1057/9780230393059

Kádár, Dániel Z. 2017. Politeness, Impoliteness and Ritual: Maintaining the Moral Order in Interpersonal Interaction. Cambridge: Cambridge University Press. https://doi.org/10.1017/9781107280465

Kádár, Dániel Z., and Melvin De La Cruz. 2016. "Rituals of Outspokenness and Verbal Conflict.” Pragmatics \& Society 7 (2): 265-290. https://doi.org/10.1075/ps.7.2.05kad

Kádár, Dániel Z., and Saeko Fukushima. 2018. “The Meta-conventionalisation and Moral Order of E-practices: A Japanese Case Study.” Internet Pragmatics: Special Issue (Im)politeness and Moral Order in Online Interactions 1 (2): 352-378. https://doi.org/10.1075/ip.00016.kad

Kádár, Dániel Z., and Juliane House. 2019a. "Ritual Frames: A Contrastive Pragmatic Approach.” Pragmatics. https://doi.org/10.1075/prag.19018.kad

Kádár, Dániel Z., and Juliane House. 2019b. "Introduction: The Pragmatics of Ritual." Pragmatics. https://doi.org/10.1075/prag.19016.kad

Kádár, Dániel Z., and Juliane House. Forthcoming. "Linguistic Forms, Standards Situations and Ritual Frames: A Contrastive Pragmatic Framework." Poznan Studies in Contemporary Linguistics.

Kádár, Dániel Z., and Rosina Márquez-Reiter. 2015. “( $\mathrm{Im})$ politeness and (Im)morality: Insights from Intervention." Journal of Politeness Research 11 (2): 239-260. 
Kádár, Dániel Z., and Puyu Ning. 2019. "Ritual Public Humiliation: Using Pragmatics to Model Language Aggression”. Acta Linguistica Academica 66 (2): 189-208. https://doi.org/10.1556/2062.2019.66.2.3

Kádár, Dániel Z., Vahid Parvaresh, and Puyu Ning. 2019. "Morality, Moral Order, and Language Conflict and Aggression - A Position Paper." Journal of Language Aggression and Conflict: Special Issue - Morality, the Moral Order, and Language Conflict and Aggression. https://doi.org/10.1075/jlac.00017.kad

Kangasharju, Helena. 2002. "Alignment in Disagreement: Forming Oppositional Alliances in Committee Meetings.” Journal of Pragmatics 34: 1447-1471. https://doi.org/10.1016/So378-2166(02)00073-5

Kienpointner, Manfred. 2018. "Impoliteness Online Hate Speech in Online Interactions." Internet Pragmatics: Special Issue - (Im)politeness and Moral Order in Online Interactions 1 (2): 329-351. https://doi.org/10.1075/ip.ooo15.kie

Levinson, Stephen. 1981. Pragmatics. Cambridge: Cambridge University Press.

Lewandowska-Tomaszczyk, Barbara, and Paul A. Wilson. 2017. "Shame and Guilt across Cultures.” In The International Encyclopedia of Intercultural Communication, ed. by Young Yun Kim, 1-9. London: Wiley. https://doi.org/10.1002/9781118783665.ieicco260

Li, Lijing. 2009. "Television and Dispute Resolution as the Fourth Mediation Paradigm: Analysis and Evaluation Based on the 'Inviting Interested Parties' Program Model." Journal of Southwestern College of Politics and Law 11: 121-129.

Lo, Adrienne, and Heidi Fung. 2011. "Language Socialization and Shaming." In The Handbook of Language Socialization, ed. by A. Duranti, E. Ochs, and B. B. Schieffelin, 169-189. Chichester: Wiley Blackwell. https://doi.org/10.1002/9781444342901.ch7

Madianou, Mirca. 2011. "News as a Looking Glass: Shame and the Symbolic Power of Mediation.” International Journal of Cultural Studies 15 (1): 3-16. https://doi.org/10.1177/1367877911411795

Márquez-Reiter, Rosina, and Michael Haugh. 2019. "Denunciation, Blame and the Moral Turn in Public Life." Discourse, Context \& Media 28: 35-43. https://doi.org/10.1016/j.dcm.2018.09.001

Márquez-Reiter, Rosina, and Sarah Orthaber. 2018. "Exploring the Moral Compass: Denunciations in a Facebook Carpool Group." Internet Pragmatics 1 (2): 241-270. https://doi.org/10.1075/ip.ooo12.mar

Parvaresh, Vahid, and Tayebi Tahmineh. 2018. "Impoliteness, Aggression and the Moral Order." Journal of Pragmatics 132: 91-107. https://doi.org/10.1016/j.pragma.2018.05.010 Petley, Jacob. 2013. "Public Interest or Public Shame." In Media and Public Shaming: Drawing the Boundaries of Disclosure Account, ed. by J. Petley, 19-29. Oxford: Oxford University Press. https://doi.org/10.5040/9780755694518.ch-002

Ran, Yongping, and Linsen Zhao. 2019. "Building Mutual Affection-Based Face in Conflict Mediation: A Chinese Relationship Management Model.” Journal of Pragmatics 129: 185-198. https://doi.org/10.1016/j.pragma.2018.01.013

Rowbottom, Jacob. 2013. “To Punish, Inform, and Criticize: The Goals of Naming and Shaming." In Media and Public Shaming: Drawing the Boundaries of Disclosure, ed. by J. Petley, 1-18. London: I. B. Tauris. https://doi.org/10.5040/9780755694518.ch-001

Scheff, Thomas J. 1988. "Shame and Conformity: The Deference-Emotion System." American Sociological Review 53: 395-406. https://doi.org/10.2307/2095647

Scheff, Thomas J. 2003. "Shame in Self and Society". Symbolic Interaction 26 (2): 239-262. https://doi.org/10.1525/si.2003.26.2.239 
Schieffelin, Bambi B. 1986. “Teasing and Shaming in Kaluli Children's Interactions." In Language Socialization across Cultures, ed. by B. B. Schieffelin, and E. Ochs, 165-181. New York: Cambridge University Press.

Sinkeviciute, Valeria. 2018. “'Ya bloody drongo!!!' Impoliteness as Situated Moral Judgement on Facebook." Internet Pragmatics: Special Issue - (Im)politeness and Moral Order in Online Interactions 1 (2): 271-302. https://doi.org/10.1075/ip.00013.sin

Spencer-Oatey, Helen. 2002. "Managing Rapport in Talk: Using Rapport Sensitive Incidents to Explore the Motivational Concerns Underlying the Management of Relations." Journal of Pragmatics 34 (5): 529-545. https://doi.org/10.1016/S0378-2166(01)00039-X

Spencer-Oatey, Helen. 2005. "(Im)politeness, Face and Perceptions of Rapport: Unpackaging Their Bases and Interrelationships.” Journal of Politeness Research 1 (1): 95-119. https://doi.org/10.1515/jplr.2005.1.1.95

Spencer-Oatey, Helen, and Dániel Z. Kádár. 2016. “The Bases of (Im)Politeness Evaluations: Culture, the Moral Order and the East-West Debate." East Asia Pragmatics 1 (1): 73-106. https://doi.org/10.1558/eap.v1i1.29084

Stewart, Charles. 2015. "Honor and Shame." In International Encyclopedia of the Social and Behavioral Sciences, 2nd edition, ed. by Nail J. Smelser, and Paul B. Baltes, 181-184. London: Pergamon. https://doi.org/10.1016/B978-0-08-097086-8.12086-o

Sung, Kyu-Talk. 1998. "An Exploration of Actions of Filial Piety." Journal of Aging Studies 12: 369-386. https://doi.org/10.1016/So890-4065(98)90025-1

Tayebi, Tahmineh. 2016. "Why Do People Take Offence? Exploring the Underlying Expectations." Journal of Pragmatics 101: 1-17. https://doi.org/10.1016/j.pragma.2016.05.006 Taylor, Gabriele. 1985. Pride, Shame, and Guilt: Emotions of Self-Assessment. New York: Oxford University Press.

Terkourafi, Marina, and Dániel Z. Kádár. 2017. “Convention and Ritual (Im)politeness”. In The Palgrave Handbook of Linguistic (Im)politeness, ed. by C. Jonathan, H. Michael, and D.Z. Kádár, 171-195. Basingstoke: Palgrave Macmillan. https://doi.org/10.1057/978-1-137-37508-7_8

Turner, Victor. 1979. "Frame, Flow and Reflection: Ritual and Drama as Public Liminality." Japanese Journal of Religious Studies 6 (4): 465-499. https://doi.org/10.18874/jjrs.6.4.1979.465-499

Welten, Stephanie C. M., Marcel Zeelenberg, and Seger M. Breugelmans. 2012. "Vicarious Shame." Cognition and Emotion 26 (5): 836-846. https://doi.org/10.1080/02699931.2011.625400

Whutnow, Robert. 1989. Meaning and Moral Order: Explorations in Cultural Analysis. Berkeley: University of California Press.

Williams, Bernard A.O. 1993. Shame and Necessity. Berkeley: University of California Press. Yang, Guoshu. 2012. "Analyzing the Concept of Chinese Filial Piety.” In Chinese Psychology, ed. by G. S. Yang, 32-59. Peking: China Renmin University Press.

Zhao, Linsen, and Yongping Ran. 2019. "Impoliteness Revisited: Evidence from Qingmian Threats in Chinese Interpersonal Conflicts." Journal of Politeness Research 15 (2): 257-291. https://doi.org/10.1515/pr-2017-0027 


\title{
Address for correspondence
}

\author{
Dániel Z. Kádár \\ Dalian University of Foreign Languages \\ Research Institute for Linguistics \\ Hungarian Academy of Sciences \\ 6 Lushun Nanlu Xiduan \\ Dalian 116044 \\ China \\ dannier@dlufl.edu.cn
}

\section{Biographical notes}

Yongping Ran is a full professor at Centre for Linguistics and Applied Linguistics at Guangdong University of Foreign Studies, Guangzhou, P.R. China. He is Director of the Centre and Yunshan Chair Professor of the university. He is Editor-in-Chief of the linguistics journal Xiandai Waiyu. His research interests include general pragmatics, interpersonal pragmatics, and (im)politeness in Chinese contexts, he has publications in Journal of Pragmatics, Intercultural Pragmatics, Journal of Politeness Research, Pragmatics and Society, and in some top journals of linguistics in China. He has also published books on pragmatics in Chinese.

Linsen Zhao is Lecturer at School of English and Education and a researcher at Centre for Linguistics and Applied Linguistics at Guangdong University of Foreign Studies, Guangzhou, P.R. China. He received a Ph.D. in pragmatics from Guangdong University of Foreign Studies. His research interests include pragmatics, in particular (im)politeness, conflict resolution and mediation discourse. He has publications in Journal of Pragmatics, Journal of Politeness Research, etc.

Dániel Z. Kádár (D.Litt, FHEA, PhD) is Chair Professor and Director of the Center for Pragmatic Research at Dalian University of Foreign Languages, China. He is also Research Professor and Head of Research Centre at the Research Institute for Linguistics, Hungarian Academy of Sciences. He is author of 23 books and edited volumes, published with publishing houses of international standing such as Cambridge University Press. He is co-editor of Contrastive Pragmatics: A Cross-Disciplinary Journal. His research interests include the pragmatics of ritual, linguistic (im)politeness research, language aggression, contrastive, intercultural and historical pragmatics. He is particularly keen on the research of Chinese language use. His most recent book is Politeness, Impoliteness and Ritual: Maintaining the Moral Order in Interpersonal Interaction (Cambridge University Press, 2017). 


\section{Publication history}

Date received: 26 April 2019

Date accepted: 19 December 2019

Published online: 4 February 2020 